\title{
Management of chronic hepatitis C: Consensus guidelines
}

\author{
Morris Sherman MD PhD ${ }^{1}$, Stephen Shafran $M D^{2}$, Kelly Burak $M D^{3}$, Karen Doucette $M D^{2}$, Winnie Wong $M D^{2}$, \\ Nigel Girgrah $M D^{1}$, Eric Yoshida $M D^{4}$, Eberhard Renner $M D^{5}$, Philip Wong $M D^{6}$, Marc Deschênes $M D^{6}$
}

\begin{abstract}
M Sherman, S Shafran, K Burak, et al. Management of chronic hepatitis C: Consensus guidelines. Can J Gastroenterol 2007;21(Suppl C):25C-34C.
\end{abstract}

Since the last consensus conference on the management of chronic viral hepatitis, a number of studies looking at modifications of the standard course of treatment have been published. These changes have been sufficiently substantive to warrant review to determine whether any changes in the recommended treatment algorithms are needed. A consensus development conference was held in January 2007, and the present document highlights the results of the presentations and discussion about these issues. It reviews the epidemiology of hepatitis $\mathrm{C}$ in Canada, treatment of acute hepatitis $\mathrm{C}$ and new algorithms in chronic hepatitis $\mathrm{C}$, including retreatment of previous treatment failures. In addition, sections on management of hepatitis $\mathrm{C}$ in special populations have been updated. There is also a section on the use of hematopoietic growth factors to help manage patients on therapy. The document should be read in conjunction with the previous document to identify changes. Some recommendations made in the previous document remain and are not discussed here.

Key Words: Acute hepatitis C; Chronic hepatitis C; Epidemiology; Erythropoietin

\section{EPIDEMIOLOGY OF HEPATITIS C IN CANADA}

Chronic hepatitis $\mathrm{C}$ continues to be a significant medical and economic burden to Canadians. It is associated with an excess mortality that will continue to increase for many years into the future (Figure 1). Infected individuals may have a diminished quality of life.

There are no large-scale representative studies to determine the prevalence of chronic hepatitis $\mathrm{C}$ in Canada. However, sophisticated modelling techniques suggest that the prevalence is approximately $0.8 \%$ to $1 \%$ and increasing over time (1). The annual estimated hepatitis C-related mortality and the rate of cure on therapy is exceeded by the number of new infections and the number of infected persons immigrating to Canada, so that the prevalence of hepatitis $\mathrm{C}$ virus (HCV) infection is increasing and will continue to increase for the foreseeable future (Table 1). Currently, approximately $65 \%$ of the estimated cases in Canada have been identified. Predictions are that by 2022, the number of hepatitis C-related deaths will increase by one-third (Figure 1) (1).

Approximately 20\% of hepatitis C in Canada occurs in the immigrant community, where access to health care may be less than optimal (1). Countries with high prevalence rates for hepatitis $\mathrm{C}$, and that provide Canada with immigrants, include

\section{La prise en charge de l'hépatite $\mathrm{C}$ chronique : Des lignes directrices consensuelles}

\begin{abstract}
Depuis la dernière conférence consensuelle sur la prise en charge de l'hépatite virale chronique, plusieurs études ont été publiées sur les modifications de l'évolution standard du traitement. Ces changements ont été assez importants pour justifier un examen afin de déterminer s'il faut modifier les algorithmes de traitement recommandés. Une conférence d'élaboration de lignes directrices consensuelles a eu lieu en janvier 2007, et le présent document expose les résultats des présentations et des discussions sur le sujet. Il traite de l'épidémiologie de l'hépatite $\mathrm{C}$ au Canada, du traitement de l'hépatite $\mathrm{C}$ aiguë et des nouveaux algorithmes de l'hépatite $\mathrm{C}$ chronique, $\mathrm{y}$ compris une reprise du traitement après des échecs thérapeutiques. De plus, on a mis à jour les parties sur la prise en charge de l'hépatite $C$ dans les populations spéciales. Une autre partie porte sur le recours aux facteurs de croissance hématopoḯtiques pour contribuer à prendre en charge les patients en cours de traitement. Il faut lire le présent document conjointement avec le document précédent afin de déterminer les changements apportés. Certaines recommandations énoncées dans le document précédent demeurent valables et ne sont pas abordées dans celui-ci.
\end{abstract}

Egypt, Somalia, Pakistan, Bangladesh and Vietnam. In addition, immigrants from southern Europe (mainly Italy, Greece and Spain) who came to Canada years ago have a high prevalence of hepatitis $\mathrm{C}$, often due to silent epidemics in their home countries between the end of World War II and approximately 1975. HCV infection from transfusion of blood products accounts for only approximately $13 \%$ of all cases. Injection drug use (IDU), current or past, accounts for more than $56 \%$ of all HCV infections in Canada (Table 2).

Almost all new HCV infections acquired in Canada are related to IDU through sharing of injection equipment. However, immigration now contributes approximately $33 \%$ of all new cases of hepatitis $\mathrm{C}(1)$.

Given the alarming estimates of future disease burden, more accurate information about the incidence and prevalence of hepatitis $\mathrm{C}$ and its complications are urgently needed to inform health care planning and resource allocation.

Recommendation 1: A large-scale, population-based seroprevalence survey should be mounted to accurately assess the prevalence of hepatitis $\mathrm{C}$ in Canada. The design of the study should take into account the known risk factors and specifically sample populations with known high endemicity (III [see Table 3 for levels of evidence]).

${ }^{1}$ Department of Medicine, University of Toronto, Toronto, Ontario; ${ }^{2}$ Department of Medicine, University of Alberta, Edmonton; ${ }^{3}$ Department of

Medicine, University of Calgary, Calgary, Alberta; ${ }^{4}$ Department of Medicine, University of British Columbia, Vancouver, British Columbia;

${ }^{5}$ Department of Medicine, University of Manitoba, Winnipeg, Manitoba; ${ }^{6}$ Department of Medicine, McGill University, Montreal, Quebec

Correspondence: Dr Morris Sherman, Toronto General Hospital, Room NCSB 11C-1252, 585 University Avenue, Toronto, Ontario M5G 2 N2.

Telephone 416-340-4756, fax 416-591-2107, e-mail morris.sherman@uhn.on.ca 


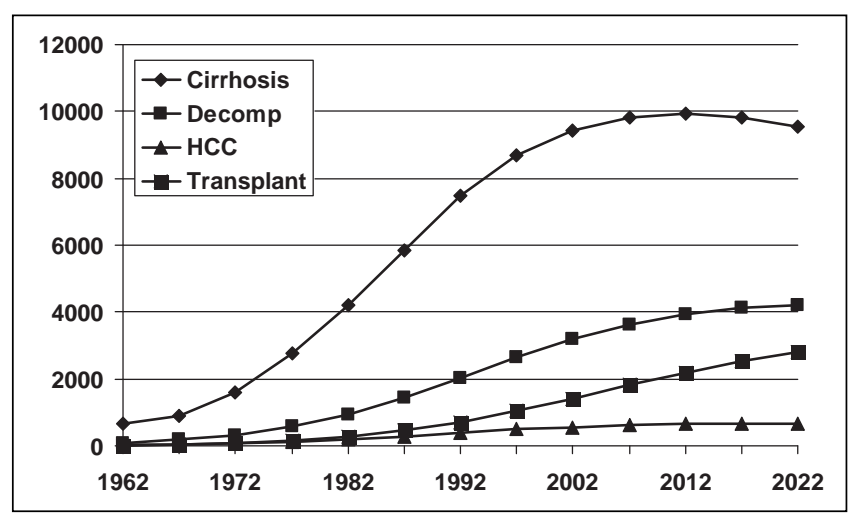

Figure 1) Modelled prevalence of hepatitis $\mathrm{C}$ virus sequelae in Canada, 1962 to 2022. Reproduced from reference 1. Decomp Decompensated liver disease; HCC Hepatocellular carcinoma

\section{TABLE 1}

Estimated hepatitis C virus (HCV) prevalence in Canada, July 1998 to December 2002

\begin{tabular}{lr}
\hline HCV prevalence, July 1998 & 240,000 \\
Annual new infections & 6600 \\
HCV immigration & 2000 \\
Annual mortality & 4700 \\
HCV prevalence, December 2002 & 253,300 \\
\hline
\end{tabular}

Recommendation 2: The current surveillance and data collection and reporting process needs to be expanded to better capture the incidence of new cases (III).

Recommendation 3: Steps must be taken to reduce the incidence of $\mathrm{HCV}$ infection among injection drug users and users of crack cocaine. These may include expansion of safe injection sites and needle exchange programs, and provision of single-use injection or crack-smoking equipment. Legal impediments to such programs must be removed. This is not a crime issue; this is a public health issue because injection drug users are increasingly becoming the reservoir for new infections (III).

Recommendation 4: Programs should be established to identify the approximately $35 \%$ of HCV-infected individuals who are unaware of their infection because there is curative therapy. For those for whom cure is not possible, lifestyle modifications to reduce the rate of disease progression can be advised (III).

\section{ACUTE HEPATITIS C}

Most cases of acute hepatitis $\mathrm{C}$ are asymptomatic and seldom diagnosed. Nonetheless, acute hepatitis $\mathrm{C}$ represents an opportunity to offer effective therapy. Acute hepatitis $\mathrm{C}$ is usually diagnosed under three circumstances: documented seroconversion, known exposure (eg, needle-stick exposure) and acute, clinical hepatitis.

There has been a high rate of spontaneous clearance of virus following acute hepatitis $\mathrm{C}$, which was more than $50 \%$ in some studies (2). The younger the age of the infection, the more likely is spontaneous clearance of the virus. Icteric hepatitis predicts spontaneous clearance with a high accuracy. Clearance usually occurs within 14 weeks of exposure. Most patients clear virus within 12 weeks. However, a single negative
TABLE 2

Hepatitis C virus (HCV) prevalence by exposure category in Canada, 2002

\begin{tabular}{lrccc}
\hline & Population & $\begin{array}{c}\text { HCV prevalence } \\
\text { rate, } \%\end{array}$ & $\begin{array}{c}\text { HCV } \\
\text { prevalence }\end{array}$ & $\begin{array}{c}\text { Proportion, } \\
\%\end{array}$ \\
\hline IDU & 91,000 & 55 & 49,900 & 20 \\
Previous IDU & 181,400 & 49 & 89,400 & 36 \\
IDU, total & 272,500 & & 139,300 & 56 \\
Transfusion & $2,748,200$ & 1.2 & 32,900 & 13 \\
Hemophilia & & 57 & 1200 & 0.5 \\
Other & $28,023,900$ & 0.26 & 73,800 & 30 \\
Total & $31,046,600$ & 0.80 & 247,200 & 100 \\
\hline
\end{tabular}

IDU Injection drug use

TABLE 3

\begin{tabular}{ll} 
Levels of evidence according to study design \\
\hline Grade & Definition \\
\hline I & Randomized controlled trials \\
II-1 & Controlled trials without randomization \\
II-2 & Cohort or case-controlled studies \\
II-3 & Multiple time series, dramatic uncontrolled experiments \\
III & Opinion of respected authorities; descriptive epidemiology
\end{tabular}

Data from reference 97

HCV RNA is insufficient to confirm clearance, and the test should be repeated at least once.

Because seroconversion is unpredictable, treatment should be considered in all patients. Treatment is most effective when started before 12 weeks $(3,4)$. Sustained virological response (SVR) rates of greater than $90 \%$ have been described using pegylated interferon (PEG IFN) monotherapy (5-7).

Recommendation 5: Patients with acute, icteric hepatitis C can be observed for up to 12 weeks to determine whether spontaneous clearance occurs. If clearance has not occurred, treatment should be initiated by 12 weeks (II-2).

Recommendation 6: In patients with acute, nonicteric hepatitis $\mathrm{C}$, the likelihood of spontaneous clearance is lower, so treatment should start soon after diagnosis (II-2).

Recommendation 7: Treatment is with PEG IFN-alpha monotherapy. Genotypes 2 and 3 should be treated for 12 weeks, and genotype 1 should be treated for 24 weeks (I).

\section{CHRONIC HEPATITIS C}

Testing for hepatitis $\mathrm{C}$ should be undertaken in patients with abnormal aminotransferases and/or risk factors for contracting hepatitis C. These risk factors include past or active IDU, blood transfusion before the introduction of second-generation anti-HCV assays in 1991, and immigration from countries of high prevalence where medical procedures may have been dispensed using improperly sterilized needles or unscreened blood products $(8,9)$.

The initial test should be an antibody test against HCV (third-generation enzyme-linked immunoassay). A sensitive HCV RNA assay may be used for confirmation.

Recommendation 8: All patients with chronic hepatitis C should be assessed to determine whether they may benefit from therapy (III).

Whether treatment is offered should be decided by weighing the risks and the benefits for a particular patient. This decision 
is complex and should consider risk of disease progression to end stage, probability of a favourable response to therapy, risk of adverse effects with therapy and comorbid conditions. The patient's wishes must also be taken into consideration. Although patients with advanced liver disease are most in need of therapy, those with early disease are most likely to clear the virus.

The assessment for suitability for therapy should include a review of the patient's history for past or current psychiatric disease, seizures, cardiac or renal disease, autoimmune disease, and alcohol or drug addiction.

Further laboratory testing includes HCV genotyping and viral load, thyroid-stimulating hormone, antinuclear antibody, serum or urine beta-human chorionic gonadotropin (for women of reproductive age), and an electrocardiogram (if the patient is older than 50 years or has a history of heart disease). A fundoscopic examination to rule out retinopathy in patients over 50 years of age or who have high blood pressure or diabetes mellitus is advisable. Although IFN can induce a retinopathy, there are no data to suggest that the risk is higher or that retinopathy is more severe in patients with pre-existing retinopathy. The retinopathy resolves on withdrawal of IFN.

Liver biopsy is the most sensitive measure of severity of liver damage. Although not mandatory, it is recommended before the initiation of therapy. In patients who elect not to be treated, a biopsy showing mild disease is helpful to support that decision.

Recommendation 9: Sensitive qualitative HCV RNA testing, HCV viral load testing and genotype testing are essential to the management of patients with chronic

hepatitis C. Results should be reported in $\mathrm{IU} / \mathrm{mL}$ and be available in a timely manner (III).

Because of the theoretical risk of teratogenicity associated with ribavirin, male and female patients must use effective contraception while on therapy and for six months after completion of therapy. However, no associated fetal abnormalities have been described in pregnancies where either parent was taking ribavirin at the time of conception or in early pregnancy.

Despite more effective and tailored therapy, it appears that less than one-third of patients in large hepatitis $\mathrm{C}$ clinics have been treated (10). The most common reasons for ineligibility other than patient refusal include a high likelihood of noncompliance, low blood counts, advanced age, psychiatric conditions, substance abuse, coronary disease, cerebrovascular disease, retinopathy, uncontrolled diabetes, autoimmune disorders and serious pulmonary disease.

\section{CONTRAINDICATIONS}

There are very few absolute contraindications to treatment (Table 4). There are anecdotal reports of successful therapy in patients who might have been excluded from therapy for most of the previously defined contraindications. Therefore, most contraindications are considered to be relative rather than absolute. In most cases, treatment of these patients requires a high degree of expertise, and therefore patients with relative contraindications should be treated in expert centres. A history of substance abuse is not a contraindication to therapy. Stable patients on a methadone maintenance program can be treated successfully (11). Patients who do not achieve complete abstinence from alcohol can also be treated successfully (12). Recent alcohol use reduces the likelihood of completing treatment, but for those who complete treatment, the response is similar to nondrinkers. Patients with prior alcohol or other

\begin{tabular}{ll}
$\begin{array}{l}\text { TABLE } 4 \\
\text { Contraindications for treatment with pegylated interferon } \\
\text { and ribavirin }\end{array}$ \\
\hline $\begin{array}{l}\text { Conditions that are no } \\
\text { longer contraindications }\end{array}$ & $\begin{array}{l}\text { Sormal alanine aminotransferase } \\
\text { Neutropenia, anemia or thrombocytopenia } \\
\end{array}$ \\
& Controlled seizure disorder \\
& Older than 65 years \\
& Alcohol use \\
Relative contraindications & Major depression \\
& Major psychosis \\
& Autoimmune disease \\
Injection drug use \\
Strong but not absolute & Renal failure (including dialysis) \\
contraindications & Alcohol abuse \\
& Hepatic decompensation \\
Absolute contraindications & Coronary artery disease \\
& Solid organ transplantation (except liver) \\
& Pregnancy
\end{tabular}

substance abuse should undergo a period of abstinence before initiating therapy to allow the abstinence to become more stable. In most cases, this should be at least six months, although this can be individualized.

Low blood counts can often be corrected before therapy. Patients with normal alanine aminotransferase (ALT) should be considered for treatment; some will have significant histological liver disease. They respond to therapy in the same manner as do those with elevated ALT (13). Older patients can be treated successfully (14).

Generally, in patients with substance abuse, alcoholism and psychiatric conditions, the prime factor determining whether treatment is feasible is the likelihood of poor adherence. Patients who are likely to be nonadherent for any reason are generally not good candidates for treatment. However, adherence can be greatly enhanced when therapy is provided in a supervised, multidisciplinary setting.

Patients with a history of depression are not necessarily at a higher risk for depression on therapy. However, patients who are depressed at the start of therapy are at higher risk for worsening of symptoms. Onset of depression during therapy is not a reason to discontinue treatment because there are many antidepressants that can be used to successfully treat these symptoms. However, suicidal ideation or the development of mania are treatment-related medical emergencies and must lead to complete withdrawal of therapy.

Some conditions, such as severe cardiac disease or other causes of reduced life expectancy due to comorbid disease, or organ transplants (other than liver transplant), still represent contraindications to therapy, but generally many of the contraindications are modifiable or treatable; thus, a patient currently deemed ineligible for therapy should be re-evaluated at a later date.

\section{THERAPY FOR HCV}

The best results have been obtained with combination PEG IFN and ribavirin $(15,16)$. There are two formulations of PEG IFN available, PEG IFN-alpha-2a and PEG IFN-alpha-2b. They differ by virtue of the size and configuration of the polyethylene glycol molecules bound to the IFN molecule. The two formulations of PEG IFNs have not been compared head to head but appear to be equivalent choices for therapy. 


\section{TABLE 5}

\section{Definition of treatment responses}

\begin{tabular}{ll}
\hline Rapid virological response & $\begin{array}{r}\text { HCV RNA negative (less than } 50 \mathrm{IU} / \mathrm{mL} \text { ) } \\
\text { at week } 4\end{array}$ \\
Early virological response & $\begin{array}{r}\geq \text { log decline in HCV RNA at week 12 (EVC } \\
\text { plus PVR) or HCV RNA negative at 12 weeks } \\
\text { HCV RNA negative (less than } 50 \mathrm{IU} / \mathrm{mL} \text { ) at } \\
\text { week } 12\end{array}$ \\
Aviremic or EVC & 2 log decline in HCV RNA at week 12, but \\
Viremic response or PVR & HCV RNA still positive \\
Sustained virological & HCV RNA negative 24 weeks after end of \\
response & treatment
\end{tabular}

EVC Early virological clearance; HCV Hepatitis C virus; PVR Partial virological response

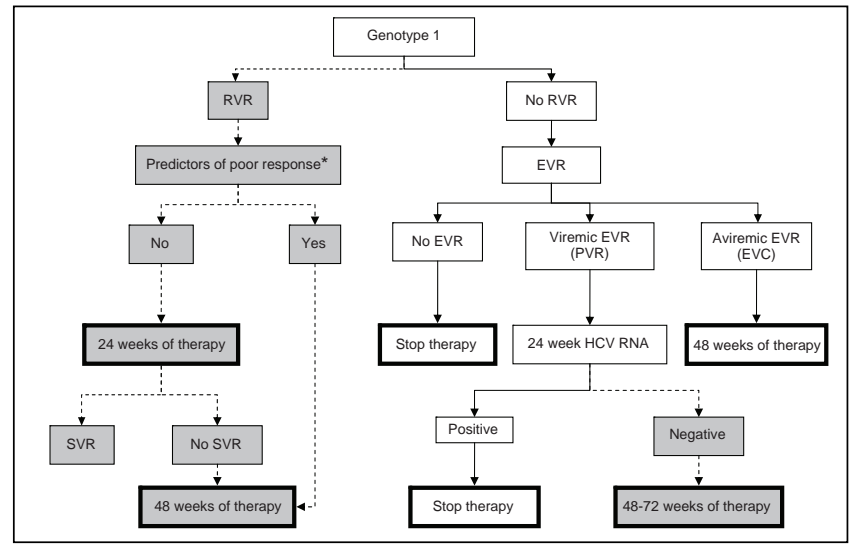

Figure 2) Algorithm for the management of patients with hepatitis $\mathrm{C}$ virus (HCV) genotype 1 infection on therapy with pegylated interferon and ribavirin. The dotted arrows and shaded boxes represent new treatment algorithms based on viral kinetics. The solid arrows and clear boxes represent the standard algorithms. *Advanced fibrosis, high viral load, high body mass index, older age, African American race, HIV coinfection or immunosuppression. EVC Early virological clearance; EVR Early virological response; PVR Partial virological response; RVR Rapid virological response; SVR Sustained virological response

The definitions of response at different time periods during therapy are given in Table 5 .

\section{RIBAVIRIN DOSE}

PEG IFN and ribavirin remains the mainstay of hepatitis C therapy. It is clear that optimizing the ribavirin exposure, particularly during the first 12 weeks of therapy, is critical for achieving a good response to therapy $(17,18)$.

Unfortunately, in Canada, ribavirin is bundled with IFN, reducing the discretion of the physician to give additional ribavirin if considered necessary. Ribavirin is dosed by weight. However, in genotype 1 infection, it is not certain whether patients weighing less than $74 \mathrm{~kg}$ will achieve the optimal results using $800 \mathrm{mg}$ of ribavirin, nor whether patients heavier than $88 \mathrm{~kg}$ will have better outcomes on $1400 \mathrm{mg}$ of ribavirin than on $1200 \mathrm{mg}$. It is also not certain whether heavier patients with genotype 2 infection need more than $800 \mathrm{mg}$ of ribavirin.

\section{STANDARD TREATMENT OF HEPATITIS C}

Standard and modified treatment algorithms are shown in Figures 2 and 3.

Recommendation 10: Genotypes 1, 4, 5 and 6 should be treated with either of the following:

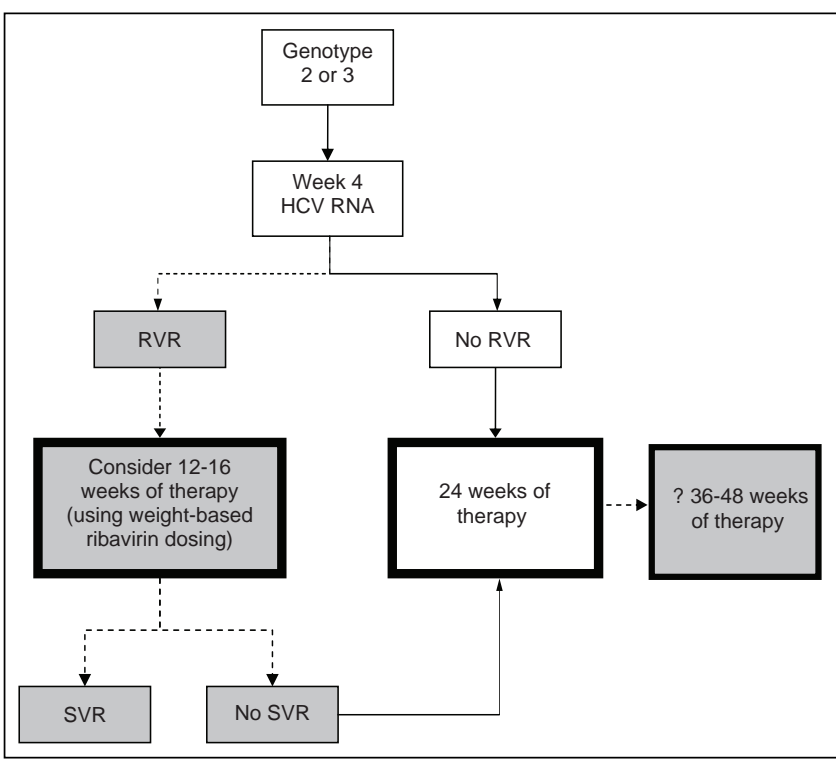

Figure 3) Algorithm for the management of patients with hepatitis $\mathrm{C}$ virus (HCV), genotype 2 or 3 , on therapy with pegylated interferon and ribavirin. The dotted arrows and shaded boxes represent new treatment algorithms based on viral kinetics. The solid arrows and clear boxes represent the standard algorithms. ? Consider 36 to 48 weeks of therapy, but the evidence is weak. RVR Rapid virological response; SVR Sustained virological response

a) PEG IFN-alpha-2a (Pegasys RBV, Hoffmann-La Roche Ltd, Canada) $180 \mu g$ subcutaneously once weekly and ribavirin $1000 \mathrm{mg}$ to $1200 \mathrm{mg}$ daily given orally in two divided doses. The dose of ribavirin given depends on whether the patient weighs more or less than $75 \mathrm{~kg}(\mathrm{I})$.

b) PEG IFN-alpha-2b (Pegetron, Schering-Plough Canada Inc) $1.5 \mu \mathrm{g} / \mathrm{kg}$ subcutaneously once weekly and ribavirin $800 \mathrm{mg}$ to $1200 \mathrm{mg}$ daily given orally in two divided doses. The dose of ribavirin depends on the patient's weight, targeting a daily dose of ribavirin greater than $13.5 \mathrm{mg} / \mathrm{kg}$, and is given orally in two divided doses (I).

Recommendation 11: Therapy is given for 48 weeks for genotypes 1, 4, 5 and 6. In patients who do not achieve an early virological response (EVR) or are still viremic after 24 weeks, therapy should be discontinued because the likelihood of SVR is negligible (I).

Recommendation 12: Genotype 2 or 3 infection should be treated with either of the following:

a) PEG IFN-alpha-2a $180 \mu$ subcutaneously once weekly and ribavirin $800 \mathrm{mg}$ daily given orally in two divided doses. There are data from randomized controlled studies and from other sources showing that for genotype 2 or 3 infection, $800 \mathrm{mg} /$ day of ribavirin is sufficient (I).

b) PEG IFN-alpha-2b $1.5 \mu \mathrm{g} / \mathrm{kg}$ subcutaneously once weekly with ribavirin. The manufacturers suggest that ribavirin be dosed by weight in this group as well, but the evidence that more than $800 \mathrm{mg} /$ day is required is not convincing (I). 
Recommendation 13: The standard duration of therapy for patients with genotype 2 or 3 infection is 24 weeks (I).

SVR rates for genotype 1 infection range from $42 \%$ to $46 \%$ $(15,16,18)$. SVR rates of $72 \%$ to $80 \%$ have been achieved for treatment of genotype 2 and 3 infections $(15,16,18)$. Although infections with genotypes other than 1,2 and 3 are less common and results of treatment are less well defined, the results appear to be better than those for genotype 1 but not as good as those for genotypes 2 and 3 .

\section{NEW REGIMENS FOR TREATMENT OF HEPATITIS C}

There is increasing evidence that the standard duration of therapy is not optimal for many patients with chronic HCV infection. Modifying the duration of therapy based on viral kinetics can maximize SVR rates while limiting the toxicities and costs associated with treatment. An essential component in the decision to shorten therapy is an assessment of rapid virological response (RVR) (Table 5).

Recommendation 14: Week 4 HCV RNA testing must be available in a timely manner to all clinicians treating chronic hepatitis C (III).

\section{Genotype 1}

In those who achieve RVR who have no predictors of poor response (advanced fibrosis, high viral load, high body mass index, older age, African American race, HIV coinfection or immunosuppression), therapy may be shortened to 24 weeks. In this subgroup, SVR rates of $88 \%$ to $89 \%$ can be achieved $(19-21)$.

Recommendation 15: Patients with genotype 1 infection and no predictors of poor response who achieve an RVR may be treated to 24 weeks (II-3). Before terminating treatment at 24 weeks, the patient should be aware that if relapse occurs, retreatment for 48 weeks will be necessary. Early withdrawal of therapy should not be undertaken unless funding is available for a second, more standard course of therapy (III).

Some patients may achieve a 2 log drop in HCV RNA by week 12 but do not achieve undetectable HCV RNA. This is defined as partial virological response (PVR) or viremic EVR. These patients may then clear HCV RNA by week 24. Such patients have been termed 'slow responders'. A preliminary study (22) suggested that prolonging therapy to 72 weeks may be of benefit in this subgroup. Subsequently, several studies (23-26) comparing 48 to 72 weeks of therapy in genotype 1 patients suggested a benefit of prolonged therapy in slow responders. Some published studies (27), however, used $800 \mathrm{mg}$ of ribavirin, and the benefit of prolonged therapy with weight-based ribavirin dosing remains uncertain.

Recommendation 16: Prolonged therapy to 72 weeks may be considered in genotype 1 patients with PVR who are HCV RNA-negative at week 24 (I). Funding for prolonged treatment should be supported by provincial drug formularies under appropriate circumstances (III).

\section{Genotypes 2 and 3}

In patients who have an RVR, 12 to 16 weeks of therapy results in SVR in $80 \%$ to $100 \%$ of genotype 2 patients and in $77 \%$ to $85 \%$ of genotype 3 patients (27-32). However, in a large, randomized trial (32), 24 weeks of therapy was superior to 16 weeks in those with RVR in both genotype 2 (91\% versus 80\%) and genotype 3 ( $89 \%$ versus $84 \%$ ) subgroups. However, this study used $800 \mathrm{mg}$ of ribavirin, and although the optimal dose of ribavirin has not been adequately defined, higher doses of ribavirin may be required in shortened regimens (33).

Recommendation 17: Patients with genotype 2 or 3 infection who achieve RVR may have therapy withdrawn at 12 or 16 weeks if they have been receiving weight-based ribavirin dosing (I). Before terminating treatment early, the patient should be aware that if relapse occurs, retreatment for 24 weeks will be necessary. Early withdrawal of therapy should not be undertaken unless funding is available for a second, more standard course of therapy (III).

RVR is the best predictor of SVR. In those who fail to achieve RVR, SVR rates with 24 weeks of therapy are disappointing, particularly in patients with genotype 3 infection (41\% to $58 \%)$, but also in patients with genotype 2 infection $(50 \%$ to $89 \%)(27-32)$. It is possible that prolonging therapy may produce a higher SVR; however, to date, no study of prolonged therapy in this population has been carried out. Further data are needed to establish the role of prolonged therapy (greater than 24 weeks) in patients with genotype 2 or 3 infection who fail to achieve an RVR. There was no consensus as to whether prolonged treatment should be offered to this group of patients.

Treatment algorithms for genotypes 1, 2 and 3 incorporating treatment decisions based on RVR are shown in Figures 2 and 3.

\section{Genotype 4}

The standard duration of therapy in patients with genotype 4 infection is 48 weeks. This results in an SVR of $40 \%$ to $79 \%$ (34-36). The week $12 \mathrm{HCV}$ RNA can be used to predict response; as in genotype 1 infection, the lack of an EVR has a high negative predictive value and treatment should be discontinued. In patients with fibrosis scores of 0 to 2 on liver biopsy and a viral load at baseline less than $800,000 \mathrm{IU} / \mathrm{mL}$, treatment duration can be shortened to 36 weeks (36).

\section{Maintenance therapy}

In addition to its antiviral action, IFN has many other properties, including antiproliferative and antiangiogenic activity, that may reduce the rate of complications in patients with advanced fibrosis who fail to achieve an SVR. Three large trials are ongoing to evaluate the role of long-term, low-dose (maintenance) therapy in this population. At the present time, there is insufficient evidence to recommend maintenance therapy in nonresponders.

\section{RETREATMENT OF PREVIOUS TREATMENT FAILURES}

Compared with the currently available PEG IFN and ribavirin combination products, the previous antiviral therapies of standard IFN monotherapy and standard IFN and ribavirin combination therapy were associated with more treatment failures. The exact number of previous treatment failures in the community is unknown, but given the number of patients treated before the licensure of the PEG IFN and ribavirin products, it is likely that the pool of standard IFN treatment failures is not inconsequential. Although the limited intrinsic potencies of the previous antiviral therapies contributed substantially to treatment failure, other secular factors, including suboptimal dosing in response to monitoring laboratory blood work or adverse clinical effects, nonadherence because of lack of nursing support, inadequate patient education and physician inexperience, may 
have contributed. It must also be appreciated that the contemporary recommendations for dose reduction and drug withdrawal are not as restrictive or cautious as in previous years given the additional years of experience with HCV IFN-based therapies in general. Thus, among patients who failed previous therapy, there is likely to be a significant proportion who failed because of early withdrawal, overly aggressive dose reductions or missed doses rather than because of true nonresponse or relapse.

There are presently seven studies $(37-43)$ that evaluated retreatment of both relapsers and nonresponders, and another large study (44) has been reported in abstract form. Of these studies, two $(37,43)$ were randomized clinical trials that compared two doses of PEG IFN-alpha-2b plus ribavirin, and the other studies were single-arm observational studies that administered PEG IFN-alpha-2b plus ribavirin or PEG IFN-alpha-2a plus ribavirin.

In general, relapsers to previous IFN-based therapy had a superior response to PEG IFN and ribavirin combination therapy (34\% to $55 \%)$ than nonresponders to previous therapy ( $8 \%$ to $26 \%$ ). Genotype 1 relapsers responded less well to PEG IFN and ribavirin combination therapy (34\% to $53 \%$ ) than nongenotype 1 patients (ie, mostly genotypes 2 and 3) (42\% to $70 \%$ ). Among nonresponders to previous standard IFN therapy, the SVR of genotype 1 patients ranged from 5\% to 22\%, whereas that of nongenotype 1 nonresponders ranged from 19\% to $57 \%$. The maximum response reported for genotype 1 nonresponders to previous combination therapy was $19 \%$ to $20 \%$. Most studies reported that the response was inversely proportional to the fibrosis score. The largest study (44), with 1046 patients, reported that among genotype 1 nonresponders to previous IFN-based therapy, the SVR ranged from $23 \%$ for those with bridging fibrosis and a platelet count greater than $125 \times 10^{9} / \mathrm{L}$ to $9 \%$ for those with cirrhosis and a platelet count of less than $125 \times 10^{9} / \mathrm{L}$. Failure to achieve EVR at week 12 of therapy has also been reported to be $100 \%$ predictive of failure to achieve SVR in genotype 1 patients. In the two studies $(37,38)$ that randomized PEG IFNalpha-2b plus ribavirin based on weight-based dosing (ie, $1.0 \mu \mathrm{g} / \mathrm{kg}$ versus $1.5 \mu \mathrm{g} / \mathrm{kg}$ of PEG IFN), a nonstatistically significant trend was reported in favour of the higher weight-based dose.

Consensus IFN has also been shown to improve the response rates in previous treatment failures, including previous failures on PEG IFN and ribavirin (45). The treatment regimens used require daily doses of IFN, and ribavirin was not part of the regimen. What role consensus IFN should play in retreating patients is not clear.

Recommendation 18: Patients who relapsed to previous standard IFN-based therapies respond well to PEG IFN and ribavirin combination therapy, regardless of genotype, and should be offered therapy (II-2).

Recommendation 19: Given the uncertainty of the treatment dose of IFN and the duration of standard IFN monotherapy, as well as its general inferiority to combination regimens with ribavirin, patients who were previous treatment failures with standard IFN monotherapy should be offered treatment with PEG IFN and ribavirin combination therapy regardless of whether the treatment failure was due to nonresponse or relapse and regardless of genotype (II-2).

Recommendation 20: Patients who were nonresponders to previous standard IFN and ribavirin combination therapy may be considered for treatment with PEG IFN and ribavirin combination therapy. If treatment is offered, a quantitative HCV RNA determination at baseline and at week 12 of therapy should be performed. Failure to achieve EVR should lead to treatment withdrawal (I).

\section{MONITORING WHILE ON THERAPY}

Therapy with PEG IFN and ribavirin is associated with numerous possible side effects. Some adverse events can be severe, even life-threatening and irreversible. Therefore, close patient monitoring by the treatment team is imperative. Laboratory monitoring during therapy involves the following: complete blood count at weeks 1, 2, 4, 6 and 8, and monthly thereafter; aspartate aminotransferase; ALT; alkaline phosphatase; bilirubin; international normalized ratio; albumin; glucose; creatinine; urinanalysis; thyroid-stimulating hormone every three months; and pregnancy testing periodically (46). RVR is assessed by qualitative HCV RNA testing at week 4. EVR is assessed by quantitative HCV RNA testing at week 12 in those with genotype 1 infection. Failure to achieve EVR should lead to treatment withdrawal. In those who achieve an EVR but do not achieve undetectable viral load, a qualitative HCV RNA test should be performed at week 24 , and a positive test should result in treatment withdrawal.

\section{MANAGEMENT OF HEPATITIS C IN SPECIAL CIRCUMSTANCES}

\section{Renal failure}

HCV infection is more frequent in dialysis patients than in the general population $(47,48)$. Anti-HCV may not be positive, even in the presence of HCV RNA. ALT elevation often does not reflect disease severity in this population. Liver biopsy may be necessary to establish disease severity, despite the potential additional bleeding risk. Transjugular biopsy can also be considered. HCV infection adversely affects patient and graft survival after kidney transplantation. However, this is not a contraindication to transplantation. Overall outcomes in $\mathrm{HCV}$-infected individuals remain within an acceptable range, with poor outcomes generally seen in those with advanced fibrosis at transplantation. IFN-based therapy before transplantation improves post-transplant outcomes $(48,49)$. IFN-based therapy increases the risk of rejection and is generally contraindicated after solid organ transplantation (except for liver transplantation).

PEG IFN-alpha $2 \mathrm{~b}$ and ribavirin are excreted by the kidneys. Ribavirin is not dialyzable. Therefore, both PEG IFNalpha-2b and ribavirin carry the risk of accumulating, resulting in an increased risk of toxicity, in patients with renal failure, particularly in those on dialysis. However, both PEG IFN alpha-2a and PEG IFN-alpha-2b have recently been used in small series (50-52) of HCV-infected hemodialysis patients, in combination with very low dose ribavirin. The ribavirin dose was controlled by ribavirin blood level monitoring. Despite reported SVR rates of $20 \%$ to $70 \%$ and an acceptable tolerability (except for an increase in erythropoietin requirements), the database is too small to allow general recommendations. At this point, patients with advanced renal failure should only be treated with PEG IFN and ribavirin in specialized centres that are able to perform ribavirin blood level monitoring. In patients with end-stage renal disease, hepatitis $\mathrm{C}$ treatment should generally be reserved for those who are candidates for renal transplantation. IFN is poorly tolerated in this population and response rates to treatment are low. Competing risks for mortality in this population also reduce the likelihood of benefit from hepatitis $\mathrm{C}$ treatment. 


\section{Recommendation 21: Treatment of hepatitis $\mathrm{C}$ in renal failure is best undertaken in conjunction with a nephrologist, and should be reserved for experts (III).}

\section{Decompensated liver disease}

PEG IFN and ribavirin have limited efficacy and a poor safety and tolerability profile in patients with decompensated liver disease (53-55). Anti-HCV treatment in these patients should never delay referral for transplant evaluation, and should only be carried out at a liver transplantation or other expert centre.

Recommendation 22: Treatment of patients with decompensated liver disease should be conducted in conjunction with a liver transplant team and by physicians familiar with the management of these diseases (III).

\section{Solid organ transplantation}

IFN is usually contraindicated after solid organ transplantation because of the risk of exacerbating rejection. Loss of kidney grafts has been reported after IFN use. In patients with lifesustaining organ transplants (eg, heart or lung), IFN should be avoided given the risk of rejection and graft loss. In renal transplant recipients, IFN-based therapy may be considered in those with progressive HCV-related liver disease or HCV-induced renal disease if the benefits are thought to outweigh the risks (rejection, graft loss and return to dialysis) and after discussion with the patient.

However, IFN can be used post-liver transplantation for treatment of hepatitis C. Rejection may occur in this setting but is generally easily treated if detected early.

Treatment of hepatitis $\mathrm{C}$ in transplant recipients should only be conducted in expert centres.

\section{Cryoglobulinemia}

Mixed type II cryoglobulinemia is present in up to $50 \%$ of patients with HCV infection and may lead to symptomatic vasculitis in a minority of patients. SVR rates of $44 \%$ to $78 \%$ have been achieved with PEG IFN and ribavirin in small series of patients (56-58). SVR was associated with clinical improvement of the vasculitis in the majority of, but not all, patients (59). Patients with symptomatic type II cryoglobulinemia vasculitis may benefit from antiviral combination therapy, even if viral eradication is not achieved. The optimal therapeutic scheme remains to be defined. There is insufficient information to make any specific recommendations.

\footnotetext{
Chronic anemia

Antiviral therapy with standard dose PEG IFN-alpha and ribavirin in HCV-infected patients with thalassemia major has been shown to be effective but increases transfusion requirements (60). As in other patients, comorbidities and the likelihood of their HCV-related liver disease ever reaching relevant morbidity and mortality during their life expectancy has to be taken into account when deciding on therapy in these patients. Similar considerations apply to patients with other forms of chronic anemia. These patients may need to be supported by transfusion during therapy rather than by the use of erythropoietin.

Recommendation 23: Patients with chronic anemia can be treated with IFN and ribavirin. This requires collaboration between the hematologist and the physician treating the hepatitis C (II-2).
}

\section{Lymphoma}

HCV infection can be associated with some forms of nonHodgkin lymphoma although a causal relationship has not consistently been documented (61-63). In small, uncontrolled series $(64,65)$, IFN-based anti-HCV therapy was reported to lead to a complete hematological response in greater than $50 \%$ of patients when associated with HCV suppression. The optimal drug dosage and duration of therapy remain to be defined. There is insufficient information to make any specific recommendations.

\section{HCV infection in hemophiliacs}

Hemophilia is not a contraindication for antiviral therapy with the current regimens of PEG IFN and ribavirin. With the exception of liver biopsy, the same criteria for indication and conduct of therapy apply as for HCV-infected patients without hemophilia. Liver biopsy is unpopular in the hemophilia population but can be safely performed by the transjugular route with appropriate clotting factor support.

\section{HCV-HIV coinfection}

Approximately 20\% of HIV-infected patients are coinfected with HCV (66). HCV-related end-stage liver disease has become the leading cause of death in these patients, accounting for $50 \%$ of all deaths in one study (67). Antiretroviral therapy slows down fibrosis progression and decreases liver-related mortality in HCV-HIV coinfection (68). The indication for treatment in HCV-HIV-coinfected patients is similar to that in monoinfected patients. Whether anti-HCV and anti-HIV therapy should be performed sequentially or simultaneously needs to be decided on an individual basis depending on the stage of HIV disease (as measured by CD4 count). Treatment with PEG IFN and ribavirin results in acceptable SVR rates, with toxicity that is not much different than in HCV monoinfected patients. SVR rates of $43 \%$ to $62 \%$ in genotypes 2 and 3 infection have been reported after 48 weeks of treatment. Studies evaluating PEG IFN plus ribavirin treatment of HCV genotypes 2 and 3 in HCV-HIV-coinfected patients have reported relapse rates of $32 \%$ to $35 \%$ when the treatment duration was 24 weeks and the ribavirin dose was $800 \mathrm{mg}$ daily $(69,70)$, although one study (71) using weight-based ribavirin dosing plus PEG IFN reported a relapse rate of $9 \%$ with 24 weeks of treatment. In contrast, the relapse rate after 48 weeks of therapy with PEG IFN plus ribavirin $800 \mathrm{mg}$ daily was $3 \%$ to $12 \%$ (72-74). In genotype 1 infection, the SVR rates were between $16 \%$ and $38 \%$. The dose of ribavirin used was $800 \mathrm{mg}$ daily. Patients who fail to achieve either a $2 \mathrm{log}$ drop in viral load after 12 weeks of therapy or undetectable virus have a negligible chance of clearing the virus. Therapy is best provided with close collaboration between an infectious disease specialist and a hepatologist. Simultaneous therapy with ribavirin and didanosine or $\mathrm{d} 4 \mathrm{t}$ increases the risk of mitochondrial toxicity (pancreatitis and hyperlactatemia) and should be avoided (75). The combination of zidovudine and ribavirin increases the risk of anemia (76). Therefore, patients on zidovudine who need treatment for hepatitis $\mathrm{C}$ should have their HIV therapy changed to eliminate zidovudine if possible.

Recommendation 24: Anti-HCV therapy should be considered in all HCV-HIV-coinfected patients. Patients should be treated with standard doses of IFN and ribavirin for 48 weeks (I). Patients who fail to achieve an EVR should be withdrawn from therapy (I). 


\section{Hepatitis C in children}

HCV infection seems to progress more slowly to fibrosis and cirrhosis in childhood-acquired disease than in adult-acquired disease $(77,78)$. Standard IFN $3 \mathrm{MU} / \mathrm{m}^{2}$ three times a week with ribavirin $15 \mathrm{mg} / \mathrm{kg} /$ day for 48 weeks yielded an SVR of $40 \%$ to $60 \%$ overall, and $70 \%$ to $100 \%$ in genotype 2 or 3 infection (79). PEG IFN-alpha-2a or $-2 b$ and ribavirin have been used in small numbers of HCV-infected children with SVR rates of $43 \%$ to $59 \%$ (higher in genotypes 2 and 3 than in genotypes 1 and 4 ) $(80,81)$. Whether EVR can be used, as in adults, to stop therapy early in patients destined to be nonresponders is not clear. The tolerability and side effect profile in children and adults appears similar except for transient growth inhibition in children.

While the medical need for therapy seems limited in the majority of HCV-infected children, antiviral therapy may be warranted in selected patients with rapidly progressive fibrosis. The exact indications for therapy remain to be better defined. Therefore, decisions about treatment are best made in specialized centres. A pretreatment liver biopsy should show significant inflammation or fibrosis. Because there are only limited data on the use of PEG IFN and ribavirin, current treatment in children remains to be standard IFN-alpha $3 \mathrm{MU} / \mathrm{m}^{2}$ subcutaneously three times a week combined with ribavirin $15 \mathrm{mg} / \mathrm{kg} /$ day orally. This leads to practical problems with ribavirin dosing with the available preparations in children younger than eight to 10 years of age because ribavirin is only available in $200 \mathrm{mg}$ tablets. Whether antiviral therapy in children carries long-term side effects remains to be seen. Children younger than three years should not be treated because of concerns of potential neurotoxicity of IFN on the developing brain. Furthermore, spontaneous viral clearance occurs with high frequency in this age group.

There is insufficient information to make any specific recommendations about treating children with hepatitis C.

\section{Injection drug users}

The prevalence of HCV infection across Canada is highest in injection drug users (greater than 50\%) (1,82-86). With more than two-thirds of new $\mathrm{HCV}$ infections today occurring through IDU, the relative importance of this patient population for HCV disease and related public health issues will further increase in the future. Injection drug users are difficult to reach with traditional medical care structures and are often psychosocially unstable, with ongoing addiction problems. They frequently have multiple medical and psychiatric comorbidities and social issues (homelessness and lack of supports), are highly mobile and fear prosecution. Given the high prevalence of HCV infection among injection drug users and the central role of this population in the HCV epidemic today, it is not justifiable to automatically exclude HCV-infected injection drug users from antiviral therapy. Although the limited data available indicate that only approximately $10 \%$ of $\mathrm{HCV}$-infected injection drug users who are potential candidates for HCV therapy actually get treated (87-90), other data suggest that $70 \%$ to $80 \%$ express an interest in being treated $(88,90)$. The low rate of uptake of therapy was due to a multitude of medical comorbidities and social problems rather than to a reluctance on the part of physicians to treat these patients. Data on treatment outcome are largely lacking.

Recommendation 25: An appropriately funded,

multidisciplinary effort is required to improve care strategies for HCV-infected injection drug users. Antiviral therapy should be considered in selected patients in whom HCV. related morbidity or mortality will likely become relevant
(II-2). This requires an integrated multidisciplinary approach reaching beyond traditional care structures.

\section{HEMATOPOIETIC GROWTH FACTOR SUPPORT IN THE MANAGEMENT OF HEPATITIS C}

Maximizing response rates to HCV therapy requires full treatment adherence to both PEG IFN and ribavirin. However, anemia due to ribavirin-induced hemolysis is often a limiting factor. Treatment-associated anemia requiring a reduction in the ribavirin dose occurs in $25 \%$ of patients, often in the first one to two months of therapy $(91,92)$, and negatively impacts the SVR. Ribavirin-induced anemia is more frequent with the higher doses of ribavirin used to treat nongenotypes 2 and 3 infection. The use of erythropoietin to stimulate red cell production has been investigated. The data clearly show that erythropoietin stimulates a rise in hemoglobin and allows a higher overall ribavirin dose to be given (91-93). These studies were recently extended and showed that the use of erythropoietin allowed higher ribavirin dosing and, thereby, improved SVR compared with a group in which erythropoietin was not used (94).

Treatment with erythropoietin may be considered if the hemoglobin falls by more than $40 \mathrm{~g} / \mathrm{L}$, or falls below $110 \mathrm{~g} / \mathrm{L}$, or if patients become symptomatic from anemia (eg, weakness, dyspnea and angina). The initial dose should be between 20,000 IU and 40,000 IU subcutaneously per week, increasing to a maximum dose of 60,000 IU per week, if required. Erythropoietin dosing is maintained to keep the hemoglobin at or above $110 \mathrm{~g} / \mathrm{L}$, but it is not necessary to aim for a return to the baseline hemoglobin level. Ribavirin-induced anemia also results in an increased consumption of red cell production factors, and thus, supplementation with iron, folic acid and vitamin B12 may be considered. Other causes of anemia need to be ruled out by laboratory testing (ie, iron, folate and vitamin B12) before attributing the anemia to medication.

Although erythropoietin can be useful, there are insufficient data to recommend its routine use in all patients.

Between $30 \%$ and $50 \%$ of patients experience a fall in neutrophil counts within the first two weeks of therapy (15-18), and neutropenia is the most common cause of IFN dose reduction. Although dose reductions or the addition of granulocyte colony-stimulating factor is commonly recommended when the neutrophil count falls to less than $0.5 \times 10^{9} / \mathrm{L}$, this does not seem to be associated with an increased risk of infection (95). Although the package inserts for both PEG IFNs (Pegasys RBV, Hoffmann-La Roche Ltd, Canada; and Pegetron, Schering-Plough Canada Inc) suggest dose reductions if the neutrophil count falls below $0.7 \times 10^{9} / \mathrm{L}$ and recommend discontinuation if the neutrophil count falls below $0.5 \times 10^{9} / \mathrm{L}$, experts suggest that dose reductions are not necessary until the neutrophil count falls below $0.5 \times 10^{9} / \mathrm{L}$, with discontinuation if the neutrophil count falls below $0.3 \times 10^{9} / \mathrm{mL}$. Because less than optimal doses of IFN have a negative impact on SVR rates, granulocyte colony-stimulating factor has been used to maintain the IFN dose (96). However, there are insufficient data to recommend the use of this agent as a standard of care.

Although the package inserts for both PEG IFNs suggest dose reductions if the platelet count falls below $75 \times 10^{9} / \mathrm{L}$ and recommend discontinuation if the platelet count falls below $50 \times 10^{9} / \mathrm{L}$, experts suggest that dose reductions are not necessary until the platelet count falls below $30 \times 10^{9} / \mathrm{L}$, with discontinuation if the platelet count falls below $20 \times 10^{9} / \mathrm{L}$. 
Recommendation 26: Erythropoietin can be used to support hemoglobin levels in patients on treatment with PEG IFN and ribavirin. However, there is insufficient evidence to recommend its use for all patients (III).

ACKNOWLEDGEMENTS: The authors would like to acknowledge the following speakers, without whose expertise the preparation of this document would not have been possible. The following speakers gave freely of their time and contributed immensely to the development of the guidelines: Robert Remis, University of Toronto; Marc Bilodeau, University of Montreal; Les Lilly, University of Toronto; George Therapondos, University of Toronto; Robert Myers, University of Calgary; David Wong, University of Toronto; Kelly Kaita, University of Manitoba; Stephen Wong, University of Manitoba; Curtis Cooper, University of Ottawa; Stephen Martin, University of Montreal; Mark Tyndall, University of British Columbia; Mark Levstik, University of Western Ontario; and Colina Yim, University Health Network.

\section{REFERENCES}

1. Remis R (personal communication). Estimating the Number of Persons Infected with Hepatitis C in Canada. Submitted to Health Canada, 2005.

2. Micallef JM, Kaldor JM, Dore GJ. Spontaneous viral clearance following acute hepatitis C infection: A systematic review of longitudinal studies. J Viral Hepat 2006; 13:34-41.

3. Jauncey M, Micallef JM, Gilmour S, et al. Clearance of hepatitis C virus after newly acquired infection in injection drug users. J Infect Dis 2004;190:1270-4

4. Wiegand J, Buggisch P, Boecher W, et al; German HEP-NET Acute HCV Study Group. Early monotherapy with pegylated interferon alpha-2b for acute hepatitis C infection: The HEP-NET acute-HCV-II study. Hepatology 2006;43:250-6.

5. Kamal SM, Fouly AE, Kamel RR, et al. Peginterferon alfa-2b therapy in acute hepatitis C: Impact of onset of therapy on sustained virologic response. Gastroenterology 2006;130:632-8. (Erratum in 2006;131:979).

6. Jaeckel E, Cornberg M, Wedemeyer H, et al; German Acute Hepatitis C Therapy Group. Treatment of acute hepatitis $\mathrm{C}$ with interferon alfa-2b. N Engl J Med 2001;345:1452-7.

7. Kamal SM, Moustafa KN, Chen J, et al. Duration of peginterferon therapy in acute hepatitis C: A randomized trial. Hepatology 2006;43:923-31. (Erratum in Hepatology 2006;44:1055).

8. Maio G, d'Argenio P, Stroffolini T, et al. Hepatitis C virus infection and alanine transaminase levels in the general population: A survey in a southern Italian town. J Hepatol 2000;33:116-20.

9. Comandini UV, Tossini G, Longo MA, et al. Sporadic hepatitis C virus infection: A case-control study of transmission routes in a selected hospital sample of the general population in Italy. Scand J Infect Dis 1998;30:11-5

10. Falck-Ytter Y, Kale H, Mullen KD, Sarbah SA, Sorescu L, McCullough AJ. Surprisingly small effect of antiviral treatment in patients with hepatitis C. Ann Intern Med 2002;136:288-92.

11. Mauss S, Berger F, Goelz J, Jacob B, Schmutz G. A prospective controlled study of interferon-based therapy of chronic hepatitis $\mathrm{C}$ in patients on methadone maintenance. Hepatology 2004;40:120-4.

12. Anand BS, Currie S, Dieperink E, et al; VA-HCV-001 Study Group. Alcohol use and treatment of hepatitis $\mathrm{C}$ virus: Results of a national multicenter study. Gastroenterology 2006;130:1607-16

13. Shiffman ML, Diago M, Tran A, et al. Chronic hepatitis $C$ in patients with persistently normal alanine transaminase levels. Clin Gastroenterol Hepatol 2006;4:645-52. (Erratum in 2006;4:1072).

14. Nudo CG, Wong P, Hilzenrat N, Deschenes M. Elderly patients are at greater risk of cytopenia during antiviral therapy for hepatitis C. Can J Gastroenterol 2006;20:589-92.

15. Manns MP, McHutchison JG, Gordon SC, et al. Peginterferon alfa-2b plus ribavirin compared with interferon alfa-2b plus ribavirin for initial treatment of chronic hepatitis C: A randomised trial. Lancet 2001;358:958-65.

16. Fried MW, Shiffman ML, Reddy KR, et al. Peginterferon alfa-2a plus ribavirin for chronic hepatitis C virus infection. N Engl J Med 2002;347:975-82.

17. Bain VG, Lee SS, Peltekian K, et al; on behalf of the Canadian PEGASYS Study Group. Exposure to ribavirin (RBV) predicts EVR and SVR in patient with HCV genotype 1 infection: analysis of the Canadian Pegasys expanded access program (EAP). Hepatology Hepatology 2006;44:335A. (Abst)

18. Hadziyannis SJ, Sette H Jr, Morgan TR, et al; PEGASYS International Study Group. Peginterferon-alpha2a and ribavirin combination therapy in chronic hepatitis C: A randomized study of treatment duration and ribavirin dose. Ann Intern Med 2004;140:346-55.

19. Ferenci P, Fried MW, Shiffman ML, et al. Predicting sustained virological responses in chronic hepatitis $\mathrm{C}$ patients treated with peginterferon alfa-2a (40 KD)/ribavirin. J Hepatol 2005;43:425-33.
20. Jensen DM, Morgan TR, Marcellin P, et al. Early identification of HCV genotype 1 patients responding to 24 weeks peginterferon alpha-2a $(40 \mathrm{kd}) /$ ribavirin therapy. Hepatology 2006;43:954-60. (Erratum in 2006;43:1410)

21. Zeuzem S, Buti M, Ferenci P, et al. Efficacy of 24 weeks treatment with peginterferon alfa-2b plus ribavirin in patients with chronic hepatitis $\mathrm{C}$ infected with genotype 1 and low pretreatment viremia. J Hepatol 2006;44:97-103.

22. Buti M, Valdes A, Sanchez-Avila F, Esteban R, Lurie Y. Extending combination therapy with peginterferon alfa-2b plus ribavirin for genotype 1 chronic hepatitis $\mathrm{C}$ late responders: A report of 9 cases. Hepatology 2003;37:1226-7.

23. Berg $\mathrm{T}$, von Wagner $\mathrm{M}, \mathrm{Nasser} \mathrm{S}$, et al. Extended treatment duration for hepatitis $C$ virus type 1: Comparing 48 versus 72 weeks of peginterferon-alfa-2a plus ribavirin. Gastroenterology 2006;130:1086-97.

24. Ferenci P, Lafen H, Scherzer TM, et al. Customizing treatment with peginterferon alfa-2A (40KD) (Pegasys[R]) plus ribavirin in patients with HCV genotype 1 or 4 infection. Hepatology 2006;44:336A. (Abstract 390)

25. Pearlman B, Ehleben $C$, Siafee $S$. Improved virologic response rates with treatment extension to 72 weeks of peginterferon alfa-2B plusweight-based ribavirin in a difficult to treat population of genotype 1 infected slow responders. Hepatology 2006;44:318A. (Abstract 343)

26. Sanchez-Tapias JM, Diago M, Escartin P, et al; TeraViC-4 Study Group. Peginterferon-alfa2a plus ribavirin for 48 versus 72 weeks in patients with detectable hepatitis $\mathrm{C}$ virus RNA at week 4 of treatment. Gastroenterology 2006;131:451-60. (Erratum in 2006;131:1363)

27. Shiffman M, Pappas S, Bacon B, et al. Utility of virologic response at weeks 4 and 12 in the prediction of SVR rates in genotype $2 / 3$ patients treated with peginterferon alfa $2 \mathrm{~A}$ plus ribavirin: Findings from ACCELERATE. Hepatology 2006;44:316A. (Abst)

28. Zeuzem S, Hultcrantz R, Bourliere M, et al. Peginterferon alfa-2b plus ribavirin for treatment of chronic hepatitis $\mathrm{C}$ in previously untreated patient infected with HCV genotypes 2 or 3. J Hepatol 2004;40:993-9. (Erratum in 2005;42:434).

29. von Wagner M, Huber M, Berg T, et al. Peginterferon-alpha-2a (40KD) and ribavirin for 16 or 24 weeks in patients with genotype 2 or 3 chronic hepatitis C. Gastroenterology 2005;129:522-7.

30. Mangia A, Santoro R, Minerva N, et al. Peginterferon alfa- $2 \mathrm{~b}$ and ribavirin for 12 vs. 24 weeks in HCV genotype 2 or 3. N Engl J Med 2005;352:2609-17.

31. Dalgard $\mathrm{O}$, Bjoro K, Hellum KB, et al. Treatment with pegylated interferon and ribavarin in $\mathrm{HCV}$ infection with genotype 2 or 3 for 14 weeks: A pilot study. Hepatology 2004;40:1260-5.

32. Shiffman M, Pappas S, Nyberg L, et al. Peginterferon alfa 2A plus ribavirin for 16 or 24 weeks in patients with HCV genotype 2 or 3: Final results of the accelerate trial. 41st Annual Meeting of the European Association for the Study of the Liver. Vienna, April 26 to 30, 2006.

33. Shiffman M, Pappas S, Greenbloom S, et al. Effect of drug exposure on sustained virologic response (SVR) in patients with chronic hepatitis $\mathrm{C}$ virus genotype 2 or 3 treated with peginterferon alfa $2 \mathrm{~A}(40 \mathrm{KD})$ plus ribavirin for 16 or 24 weeks. Hepatology 2006;44:317A. (Abstract 342)

34. Derbala M, Amer A, Bener A, Lopez AC, Omar M, El Ghannam M. Pegylated interferon-alpha 2b-ribavirin combination in Egyptian patients with genotype 4 chronic hepatitis. J Viral Hepat 2005;12:380-5.

35. Diago M, Hassanein T, Rodes J, Ackrill AM, Sedarati F. Optimized virologic response in hepatitis $\mathrm{C}$ virus genotype 4 with peginterferon-alpha2a and ribavirin. Ann Intern Med 2004;140:72-3.

36. Kamal SM, El Tawil AA, Nakano T, et al. Peginterferon \{alpha\}-2b and ribavirin therapy in chronic hepatitis $\mathrm{C}$ genotype 4 : Impact of treatment duration and viral kinetics on sustained virological response. Gut 2005;54:858-66.

37. Jacobson IM, Gonzalez SA, Ahmed F, et al. A randomized trial of pegylated interferon alpha-2b plus ribavirin in the retreatment of chronic hepatitis $\mathrm{C}$. Am J Gastroenterol 2005;100:2453-62.

38. Mathew A, Peiffer LP, Rhoades K, McGarrity T. Sustained viral response to pegylated interferon alpha-2b and ribavirin in chronic hepatitis $\mathrm{C}$ refractory to prior treatment. Dig Dis Sci 2006;51:1956-61.

39. Krawitt EL, Ashikaga T, Gordon SR, Ferrentino N, Ray MA, Lidofsky SD; New York New England Study Team. Peginterferon alfa-2b and ribavirin for treatment-refractory chronic hepatitis C. J Hepatol 2005;43:243-9.

40. Parise E, Cheinquer H, Crespo D, et al; Brazilian Pegasys Cooperative Study Group. Peginterferon alfa-2a (40KD) (PEGASYS) plus ribavirin (COPEGUS) in retreatment of chronic hepatitis $\mathrm{C}$ patients, nonresponders and relapsers to previous conventional interferon plus ribavirin therapy. Braz J Infect Dis 2006;10:11-6.

41. Taliani G, Gemignani G, Ferrari C, et al; Nonresponder Retreatment Group Pegylated interferon alfa-2b plus ribavirin in the retreatment of interferonribavirin nonresponder patients. Gastroenterology 2006;130:1098-106.

42. Sherman M, Yoshida EM, Deschenes M, et al; Canadian Pegasys Study Group. Peginterferon alfa-2a (40KD) plus ribavirin in chronic hepatitis $\mathrm{C}$ patients who failed previous interferon therapy. Gut 2006;55:1631-8.

43. Everson GT, Hoefs JC, Seeff LB, et al; HALT-C Trial Group. Impact of disease severity on outcome of antiviral therapy for chronic hepatitis C: Lessons from the HALT-C trial. Hepatology 2006;44:1675-84.

44. Poynard T, Schiff E, Terg R, et al. Sustained virologic response (SVR) in the EPIC 3 Trial: Week twelve virology predicts SVR in previous interferon/ribavirin treatment failures receiving peg-Intron/Rebetol (PR) weight based dosing (WBD). J Virol Hepatol 2005;42(Suppl 2):40-1. 
45. Cornberg M, Hadem J, Herrmann E, et al. Treatment with daily consensus interferon (CIFN) plus ribavirin in non-responder patients with chronic hepatitis C: A randomized open-label pilot study. J Hepatol 2006;44:291-301.

46. Seeff LB, Hoofnagle JH. National Institutes of Health Consensus Development Conference: Management of hepatitis C: 2002. Hepatology 2002;36(5 Suppl 1):S1-2.

47. Russo MW, Goldsweig CD, Jacobson IM, Brown RS Jr. Interferon monotherapy for dialysis patients with chronic hepatitis C: An analysis of the literature on efficacy and safety. Am J Gastroenterol 2003;98:1610-5.

48. Gonzalez-Roncero F, Gentil MA, Valdivia MA, et al. Outcome of kidney transplant in chronic hepatitis $C$ virus patients: Effect of pretransplantation interferon-alpha2b monotherapy. Transplant Proc 2003;35:1745-7.

49. Russo MW, Ghalib R, Sigal S, Joshi V. Randomized trial of pegylated interferon alpha-2b monotherapy in haemodialysis patients with chronic hepatitis C. Nephrol Dial Transplant 2006;21:437-43

50. Kokoglu OF, Ucmak H, Hosoglu S, et al. Efficacy and tolerability of pegylated-inteferon alpha-2a in hemodialysis patients with chronic hepatitis C. J Gastroenterol Hepatol 2006;21:575-80.

51. Sporea I, Sirli R, Golea O, Totolici C, Danila M, Popescu A. Peg-interferon alfa $2 \mathrm{a}(40 \mathrm{kDa})$ in patients on chronic haemodialysis with chronic hepatitis C. Preliminary results. Rom J Gastroenterol 2004;13:99-102.

52. Bruchfeld A, Lindahl K, Reichard O, Carlsson T, Schvarcz R. Pegylated interferon and ribavirin treatment for hepatitis $\mathrm{C}$ in haemodialysis patients. J Viral Hepat 2006;13:315-21

53. Iacobellis A, Siciliano M, Perri F, et al. Peginterferon alfa-2b and ribavirin in patients with hepatitis $\mathrm{C}$ virus and decompensated cirrhosis: A controlled study. J Hepatol 2007;46:206-12.

54. Everson GT, Trotter J, Forman L, et al. Treatment of advanced hepatitis C with a low accelerating dosage regimen of antiviral therapy. Hepatology 2005;42:255-62.

55. Everson GT. Treatment of chronic hepatitis $\mathrm{C}$ in patients with decompensated cirrhosis. Rev Gastroenterol Disord 2004:4(Suppl 1):S31-8.

56. Mazzaro C, Zorat F, Caizzi M, et al. Treatment with peg-interferon alfa-2b and ribavirin of hepatitis $\mathrm{C}$ virus-associated mixed cryoglobulinemia: A pilot study. J Hepatol 2005;42:632-8.

57. Cacoub P, Saadoun D, Limal N, Sene D, Lidove O, Piette JC. PEGylated interferon alfa-2b and ribavirin treatment in patients with hepatitis $\mathrm{C}$ virusrelated systemic vasculitis. Arthritis Rheum 2005;52:911-5.

58. Alric L, Plaisier E, Thebault $\mathrm{S}$, et al. Influence of antiviral therapy in hepatitis $\mathrm{C}$ virus-associated cryoglobulinemic MPGN. Am J Kidney Dis 2004;43:617-23

59. Levine JW, Gota C, Fessler BJ, Calabrese LH, Cooper SM. Persistent cryoglobulinemic vasculitis following successful treatment of hepatitis $\mathrm{C}$ virus. J Rheumatol 2005;32:1164-7.

60. Inati $\mathrm{A}$, Taher $\mathrm{A}$, Ghorra S, et al. Efficacy and tolerability of peginterferon alpha 2a with or without ribavirin in thalassaemia major patients with chronic hepatitis C virus infection. Br J Haematol 2005;130:644-6.

61. Matsuo K, Kusano A, Sugumar A, Nakamura S, Tajima K, Mueller NE. Effect of hepatitis C virus infection on the risk of non-Hodgkin's lymphoma: A meta-analysis of epidemiological studies. Cancer Sci 2004;95:745-52.

62. Engels EA, Chatterjee N, Cerhan JR, et al. Hepatitis C virus infection and non-Hodgkin lymphoma: Results of the NCI-SEER multi-center case-control study. Int J Cancer 2004;111:76-80.

63. Gisbert JP, Garcia-Buey L, Arranz R, et al. The prevalence of hepatitis C virus infection in patients with non-Hodgkin's lymphoma. Eur J Gastroenterol Hepatol 2004;16:135-8.

64. Gisbert JP, Garcia-Buey L, Pajares JM, Moreno-Otero R. Systematic review: Regression of lymphoproliferative disorders after treatment for hepatitis $\mathrm{C}$ infection. Aliment Pharmacol Ther 2005;21:653-62.

65. Vallisa D, Bernuzzi P, Arcaini L, et al. Role of anti-hepatitis C virus (HCV) treatment in HCV-related, low-grade, B-cell, non-Hodgkin's lymphoma: A multicenter Italian experience. J Clin Oncol 2005;23:468-73.

66. Amin J, Kaye M, Skidmore S, Pillay D, Cooper DA, Dore GJ. HIV and hepatitis C coinfection within the CAESAR study. HIV Med 2004;5:174-9.

67. Bica I, McGovern B, Dhar R, et al. Increasing mortality due to end-stage liver disease in patients with human immunodeficiency virus infection. Clin Infect Dis 2001;32:492-7.

68. Benhamou Y, Di Martino V, Bochet M, et al; MultivirC Group. Factors affecting liver fibrosis in human immunodeficiency virus-and hepatitis $\mathrm{C}$ virus-coinfected patients: Impact of protease inhibitor therapy. Hepatology 2001;34:283-7.

69. Perez-Olmeda M, Nunez M, Romero M, et al. Pegylated IFN-alpha2b plus ribavirin as therapy for chronic hepatitis $\mathrm{C}$ in HIV-infected patients. AIDS 2003;17:1023-8.

70. Voigt E, Schulz C, Klausen G, et al; Kaad Study Group. Pegylated interferon alpha-2b plus ribavirin for the treatment of chronic hepatitis C in HIVcoinfected patients. J Infect 2006;53:36-42.

71. Hopkins S, Lambourne J, Farrell G, et al. Role of individualization of hepatitis $\mathrm{C}$ virus (HCV) therapy duration in HIV/HCV-coinfected individuals. HIV Med 2006;7:248-54.
72. Torriani FJ, Rodriguez-Torres M, Rockstroh JK, et al; APRICOT Study Group. Peginterferon Alfa-2a plus ribavirin for chronic hepatitis $\mathrm{C}$ virus infection in HIV-infected patients. N Engl J Med 2004;351:438-50.

73. Chung RT, Andersen J, Volberding P, et al; AIDS Clinical Trials Group A5071 Study Team. Peginterferon Alfa-2a plus ribavirin versus interferon alfa-2a plus ribavirin for chronic hepatitis $\mathrm{C}$ in HIV-coinfected persons. N Engl J Med 2004;351:451-9.

74. Carrat F, Bani-Sadr F, Pol S, et al; ANRS HCO2 RIBAVIC Study Team. Pegylated interferon alfa-2b vs standard interferon alfa-2b, plus ribavirin, for chronic hepatitis $\mathrm{C}$ in HIV-infected patients: A randomized controlled trial. JAMA 2004:292:2839-48.

75. Laguno M, Murillas J, Blanco JL, et al. Peginterferon alfa-2b plus ribavirin compared with interferon alfa-2b plus ribavirin for treatment of $\mathrm{HIV} / \mathrm{HCV}$ co-infected patients. AIDS 2004;18:F27-36.

76. Alvarez D, Dieterich DT, Brau N, Moorehead L, Ball L, Sulkowski MS Zidovudine use but not weight-based ribavirin dosing impacts anaemia during HCV treatment in HIV-infected persons. J Viral Hepat 2006;13:683-9.

77. Casiraghi MA, De Paschale M, Romano L, et al. Long-term outcome ( 35 years) of hepatitis $\mathrm{C}$ after acquisition of infection through min transfusions of blood given at birth. Hepatology 2004;39:90-6.

78. Guido M, Bortolotti F, Leandro G, et al. Fibrosis in chronic hepatitis C acquired in infancy: Is it only a matter of time? Am J Gastroenterol 2003;98:660-3

79. Gonzalez-Peralta RP, Kelly DA, Haber B, et al; International Pediatric Hepatitis C Therapy Group. Interferon alfa-2b in combination with ribavirin for the treatment of chronic hepatitis $\mathrm{C}$ in children: Efficacy, safety, and pharmacokinetics. Hepatology 2005;42:1010-8.

80. Schwarz KB, Mohan P, Narkewicz MR, et al. Safety, efficacy and pharmacokinetics of peginterferon alpha2a $(40 \mathrm{kd})$ in children with chronic hepatitis C. J Pediatr Gastroenterol Nutr 2006;43:499-505.

81. Wirth S, Pieper-Boustani H, Lang T, et al. Peginterferon alfa-2b plus ribavirin treatment in children and adolescents with chronic hepatitis $\mathrm{C}$. Hepatology 2005;41:1013-8

82. Fischer RP, Haley RW. Biases in surveillance of hepatitis $\mathrm{C}$ infection systematically underestimate the etiologic role of tattooing. J Gastroenterol Hepatol 2004;19:1222-3.

83. Fischer B, Haydon E, Rehm J, Krajden M, Reimer J. Injection drug use and the hepatitis $\mathrm{C}$ virus: Considerations for a targeted treatment approach - the case study of Canada. J Urban Health 2004;81:428-47.

84. Muga R, Sanvisens A, Bolao F, et al. Significant reductions of HIV prevalence but not of hepatitis $\mathrm{C}$ virus infections in injection drug users from metropolitan Barcelona: 1987-2001. Drug Alcohol Depend 2006;82(Suppl 1):S29-33.

85. Lumbreras B, Jarrin I, del Amo J, et al. Impact of hepatitis C infection on long-term mortality of injecting drug users from 1990 to 2002: Differences before and after HAART. AIDS 2006;20:111-6.

86. Reynolds GL, Fisher DG, Jaffe A, Edwards J. Follow-up for medical care among drug users with hepatitis C. Eval Health Prof 2006;29:355-66.

87. Hagan H, Latka MH, Campbell JV, et al; Study to Reduce Intravenous Exposures Project Team. Eligibility for treatment of hepatitis $\mathrm{C}$ virus infection among young injection drug users in 3 US cities. Clin Infect Dis 2006;42:669-72.

88. Nunes D, Saitz R, Libman H, Cheng DM, Vidaver J, Samet JH. Barriers to treatment of hepatitis $\mathrm{C}$ in $\mathrm{HIV} / \mathrm{HCV}$-coinfected adults with alcohol problems. Alcohol Clin Exp Res 2006;30:1520-6.

89. Strathdee SA, Latka M, Campbell J, et al; Study to Reduce Intravenous Exposures Project. Factors associated with interest in initiating treatment for hepatitis $\mathrm{C}$ virus (HCV) infection among young $\mathrm{HCV}$-infected injection drug users. Clin Infect Dis 2005;40(Suppl 5):S304-12.

90. Doab A, Treloar C, Dore GJ. Knowledge and attitudes about treatment for hepatitis $\mathrm{C}$ virus infection and barriers to treatment among current injection drug users in Australia. Clin Infect Dis 2005;40(Suppl 5):S313-20.

91. Pockros PJ, Shiffman ML, Schiff ER, et al; PROACTIVE Study Group. Epoetin alfa improves quality of life in anemic HCV-infected patients receiving combination therapy. Hepatology 2004;40:1450-8.

92. Afdhal NH, Dieterich DT, Pockros PJ, et al; Proactive Study Group. Epoetin alfa maintains ribavirin dose in $\mathrm{HCV}$-infected patients: A prospective, doubleblind, randomized controlled study. Gastroenterology 2004;126:1302-11.

93. Dieterich DT, Wasserman R, Brau N, et al. Once-weekly epoetin alfa improves anemia and facilitates maintenance of ribavirin dosing in hepatitis $\mathrm{C}$ virus-infected patients receiving ribavirin plus interferon alfa. Am J Gastroenterol 2003;98:2491-9.

94. Shiffman ML, Price A, Hubbard S, et al. Treatment of chronic hepatitis C virus (HCV) genotype 1 with peginterferon alfa-2B (PEGIFN), high weight based dose ribavirin (RVN) and epoetin alfa (EPO) enhances sustained virologic response (SVR). Hepatology 2005;42(Suppl 1):217A. (Abst)

95. Cooper CL, Al-Bedwawi S. Infection rates in HIV-HCV patients treated with interferon are similar to those in $\mathrm{HCV}$ mono-infection and not related to neutropenia. HIV Clin Trials 2006; 7:251-4

96. Lebray P, Nalpas B, Vallet-Pichard A, et al. The impact of haematopoietic growth factors on the management and efficacy of antiviral treatment in patients with hepatitis C virus. Antivir Ther 2005;10:769-76.

97. American Gastroenterological Association Medical Position Statement: Guidelines for the use of enteral nutrition. Gastroenterology 1995;108:1280-1. 


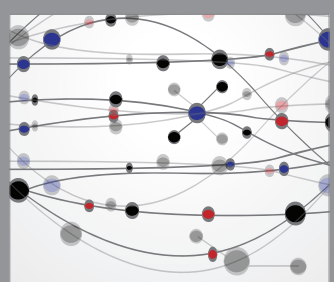

The Scientific World Journal
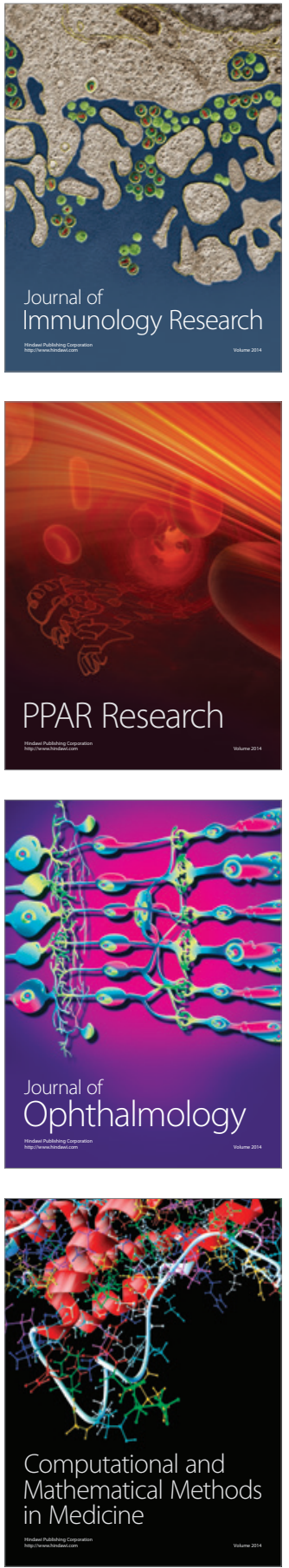

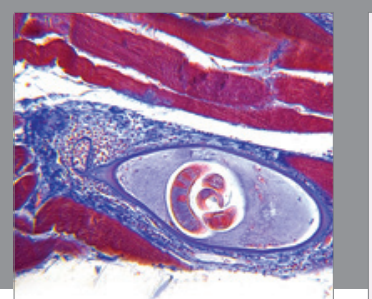

Gastroenterology Research and Practice

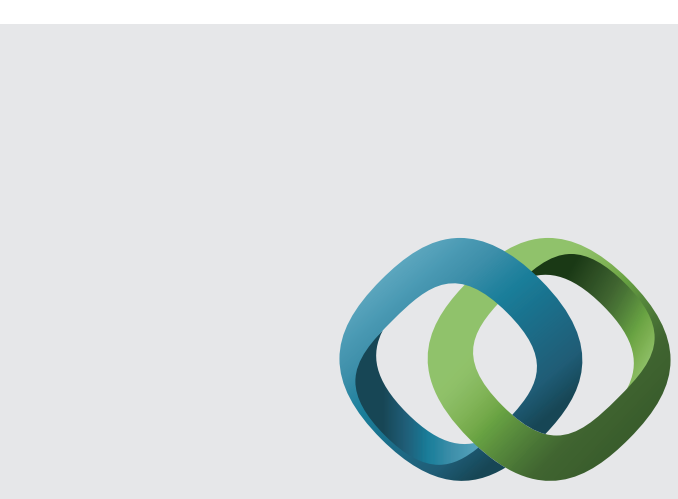

\section{Hindawi}

Submit your manuscripts at

http://www.hindawi.com
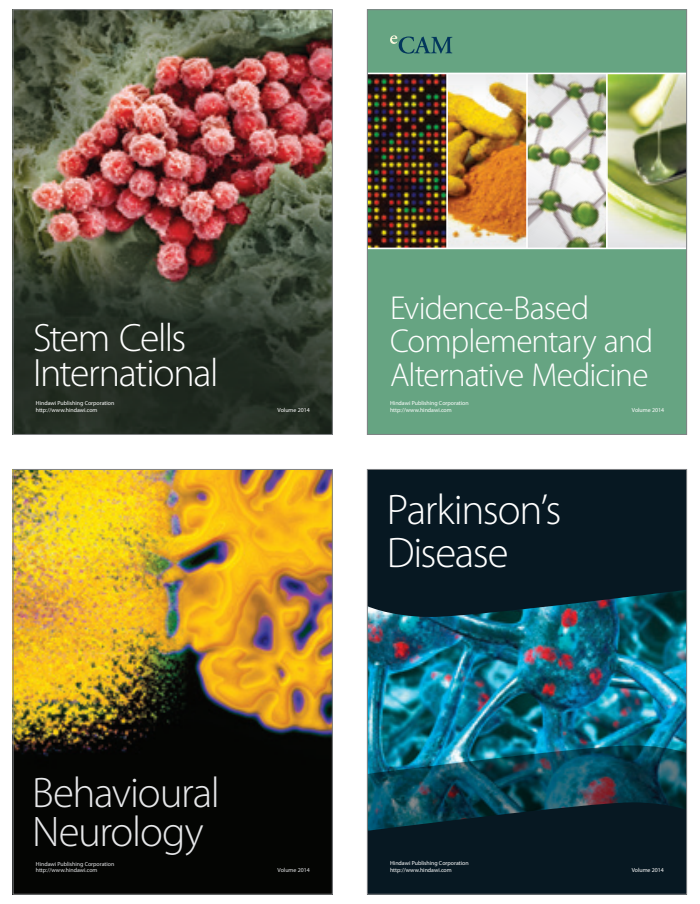
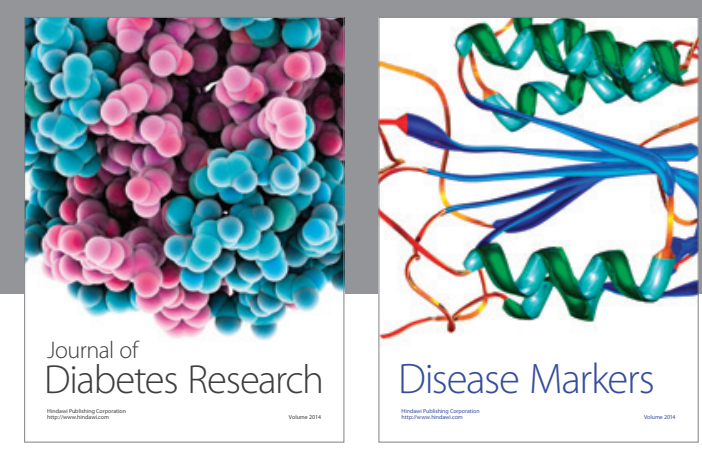

Disease Markers
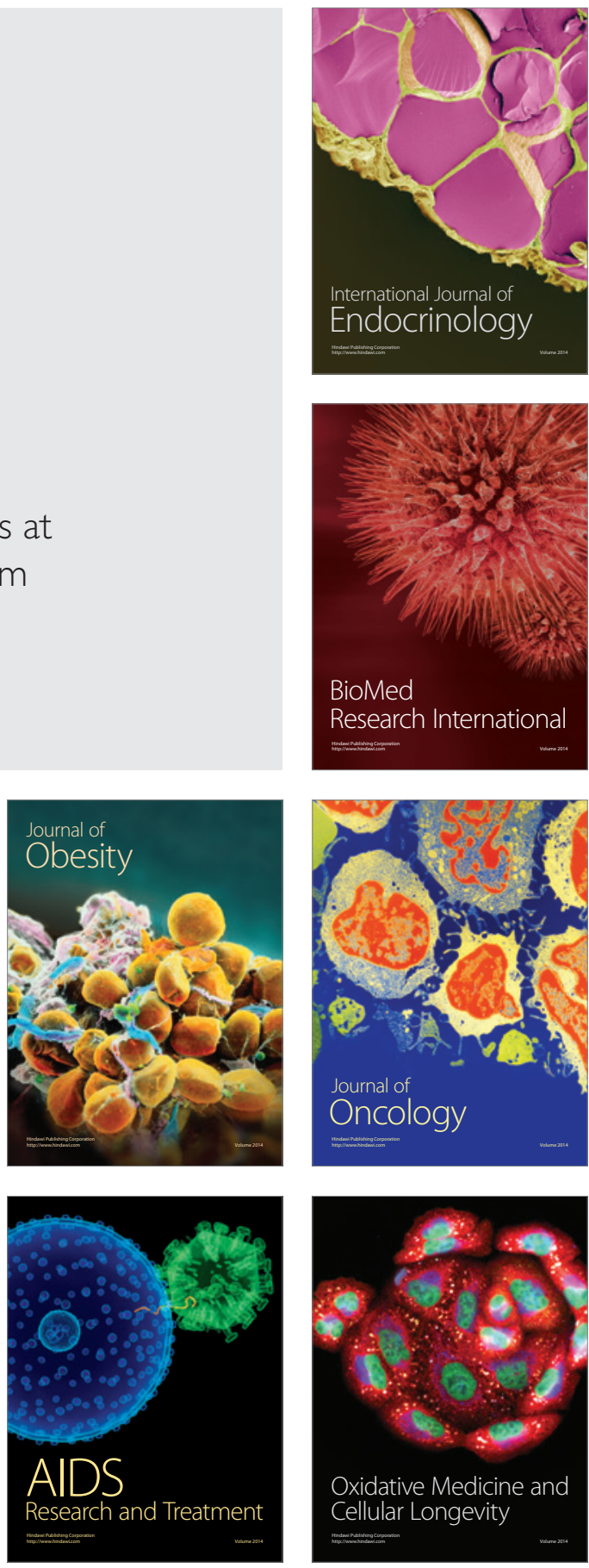